\title{
The Norwegian 9/11: In the church without a Bible
}

\author{
Ole Jakob Løland \\ University of Oslo \\ Faculty of Theology \\ Postboks 1023 Blindern \\ 0315 Oslo \\ Norway \\ o.j.loland@teologi.uio.no
}

\begin{abstract}
The article identifies roles and conditions for the Bible within modern politics in the West. By comparing the official Norwegian response to the terror attack in Oslo July 22, 2011 with the similar response in the US on September 11, 2001 it is explained why the Bible is nearly absent in the official discourse of Norwegian Prime Ministers. While religion resurfaced in the process of national recuperation with the Cathedral of Oslo as a center for mass ritualization and national grief, the biblical legacy played no part in the Prime Minister's speech. The primary political leader of the Norwegian state has rarely bolstered his argument with the Bible, although this state has officially adhered to a Protestant confession from its Constitution in 1814.

The Liberal Bible that appears to be operative in US presidential discourse is not playing a major role on a comparable political level in Norway. ${ }^{1}$
\end{abstract}

Keywords: Reception History of the Bible, Secularization, Political Theology, State-Church relations

In the years since September 11, 2001, academic discussions about the meaning of the concept of "political theology" have proliferated. Renewed attention has been given to what scholars consider to be a new visibility of the religious in the public square, particularly to the possible theological underpinnings of politics in the so-called "Western world". Religious

\footnotetext{
${ }^{1}$ I am thankful for useful criticisms of earlier versions of this paper from anonymous peer reviews as well as from the participants in the research project "Good Protestant, Bad Religion? Formatting Religion in Modern Society (GOBA)" at the University of Oslo: Vebjørn Horsfjord, Erlend Hovdkinn, Oddbjørn Leirvik, Tarald Rasmussen, Aud V. Tønnessen, and Helge Årsheim,
} 
faith has survived modernity and the theological legitimation of politics has remained as what Hent de Vries has called "an irrevocable latency". 2 The Bush era of North American politics made the potential political instrumentalisation of religion in times of terror evident, more specifically the pillar of the majority religion of United States: the Bible. In his "Address to the Nation" on the evening of September 11, 2001, the US president George W. Bush reactivated the Bible as cultural and religious icon within the political in order to persuade and console the American people in the immediate aftermath of the attack. A limited and deliberate use of the Bible worked for the politician's aim in a crucial moment, when he quoted a verse from the Book of Psalm, chapter 23. This reflected the renegotiated status of the Bible within the modern United States of the epoch-making event of 11/9.

Scholars such as Yvonne Sherwood, James Crossley, Jacques Berlinerblau and Jonathan Sheehan have contributed to the writing of a new kind of history of the Bible that is sensitive to the use of the Christian canon within Anglo-Saxon political contexts. In this research George W. Bush's Bible is considered as a modern invention of the perception that the Bible is the cornerstone and unique source for modern democracy, freedom and liberal rights. The Bible at work in his political rhetoric, no matter how little biblical text it refers to or how vague these references are, can be properly named as "the Liberal Bible". Bush is not only called by God, as attested to in his autobiography. ${ }^{3} \mathrm{He}$ is also democratically elected by the people. James Crossley has discerned the influence of what he regards as "the Radical Bible" in British politics from 1968 onwards. This is a use of the Bible based on premises that egalitarian policies such as undermining of authority, disturbance of social hierarchies or common property ownership have divine origins in the Bible. ${ }^{4}$ Furthermore, Jonathan Sheehan has come up with the notion of an "Enlightenment Bible". This is the creation of the idea of the Bible as the ultimate source of great literary works and jurisprudential virtues that laid the foundation of Western civilization. Gradually the Bible was converted from theology into culture, and transformed from a theocratic oracle into a cultural document worthy as an object of study for enlightened professionals producing modern biblical scholarship. ${ }^{5}$ The

\footnotetext{
${ }^{2}$ Hent de Vries, "Introduction," in Political Theologies: Public Religions in a Post-Secular World, ed. Hent de Vries and Lawrence Eugene Sullivan (New York: Fordham University Press, 2006), 41.

${ }^{3}$ Bradley A. Johnson, "Currency of a Calling: The American Exception, the American Dream," Postscripts: The Journal of Sacred Texts and Contemporary Worlds 2, no. 1 (2006): 88.

${ }^{4}$ James G. Crossley, Harnessing Chaos: The Bible in English Political Discourse since 1968 (London: Bloomsbury T\&T Clark, 2014), 20-29.

${ }^{5}$ Jonathan Sheehan, The Enlightenment Bible: Translation, Scholarship, Culture (Princeton: Princeton University Press, 2005).
} 
Cultural Bible was erected. These are three different Bibles produced by a modern Protestant culture over centuries and their present forms can be put to work within what have become of these religious cultures in Northern Europe and North America. In the words of Yvonne Sherwood, "biblical authority does not disappear but changes its shape". 6

When Norway July 22, 2011 was hit by the worst terrorist attack in its postwar history, the notion that the attack constituted "Norway's 9/11" rapidly surged. ${ }^{7}$ According to this view, the atrocities the Norwegian society went through this day when 77 people died because of the attacks and more than hundred were left wounded by them, were comparable to the terrorism against United States September 11, 2001. If these terror attacks led to comparable national traumas for the peoples of United States and Norway, then we could ask: which differences and similarities were there in the national leaders' reactions with regard to civil religion and more specifically with regard to the Bible?

\section{Why Bush and Stoltenberg?}

Both Jens Stoltenberg (1959-) and George W. Bush (1946-) delivered two public speeches after the attacks before the speeches in focus here. Stoltenberg's speech during the memorial service in the Cathedral July 24, 2011 was similarly to Bush's "Address to the Nation" broadcasted directly on TV and the two speeches were particularly defining for the official reaction carried out by these national leaders in the immediate aftermath of the terror incidents. ${ }^{8}$ Therefore Stoltenberg's talk on July 24, 2011 can be the most relevant to compare with Bush's “Address to the Nation”. Since the one given by Stoltenberg in the Cathedral of Oslo is one of the most remembered speeches among Norwegians, it means that one of the primary expressions of mourning and grief from the person in the highest political office of Norway became manifested in what is the symbolic and institutional center of the Lutheran Church of Norway in the capital. ${ }^{9}$ Similarly, George W. Bush's speech became the perhaps

\footnotetext{
${ }^{6}$ Yvonne Sherwood, "The God of Abraham and Exceptional States, or the Early Modern Rise of the Whig/Liberal Bible," Journal of the American Academy of Religion 76, no. 2 (2008): 316.

${ }^{7}$ Charles Hormans, "Norway's 9/11?," National Affairs, Inc; Paul Harris, "'Norway's 9/11': At Least 80 Feared Dead in Double Attack on Norwegian Capital and Holiday Island," Associated Newspapers.

${ }^{8}$ Formally, the King Harald V is the head of the state in Norway. Accordingly, Stoltenberg was not in possession of the same status as Bush as the head of the state. In this occasion, however, it was Stoltenberg who appeared as the leader of the nation.

${ }^{9}$ The cathedral of Oslo became nearly immediately after the terror attack the epicenter of the national grief. Its location is geographically near to the government buildings but far enough to be accessible for the public in the immediate aftermath of the attack. Moreover, the public spontaneously and actively appropriated its room and the streets outside for individual rituals such as lightning of candles. Olaf Aagedal, "Sørgjestad Og Kampplass.
} 
most known official reaction to the attacks. Furthermore, the places from which these speeches were held carry with them comparable cultural memories: "The Address to the Nation" as a speech given by the president sitting in the Oval Office in the White House can be regarded as a national and political ritual that, particularly in the age of television, repeats itself in times of national crisis. When George W. Bush appeared on the screen at this particular occasion of a terrorist attack, viewers would for instance be reminded of or given associations to John F. Kennedy's speech during the Cuban Missile Crisis in 1962 or Ronald Reagan's speeches on the height of the Cold War of the eighties. A broadcasted memorial service, like the one in which Stoltenberg acted, has slightly different meanings. Although the attendance at services in the Church of Norway persists at low levels and the percentage baptized and married has decreased, the number of funerals held in the church is relatively constant. Moreover, no rites de passage in the church reaches such a high percentage of the population as the funeral. $92 \%$ of all Norwegians that were interred in 2011 had a Christian funeral. ${ }^{10}$ When Norwegians gather in the Church of Norway it is often at the occasion of a burial, and here relatives or close friends often hold a memorial speech about the dead person. Accordingly, when a memorial service was held in the Cathedral of Oslo and broadcasted nationally, the pictures of the Prime Minister as layman dressed in black suit for the occasion, on the visual background of a church, would likely bring memories from funerals. Summed up, "the Address to the Nation" from the Oval Office and the layman's speech in the Church of Norway can both be considered as ritual orchestrations of societies that seek to cope with realities of death, meaninglessness and grief during national crisis.

\section{America as religious and Europe as secular}

While considerable research on the use of the Bible in US politics has been carried out, such research on Norwegian politics is scarce. ${ }^{11}$ Partly relying on previous research, ${ }^{12}$ I have

\footnotetext{
Stortorget Og Oslo Domkyrkje Etter 22. Juli," in Den Offentlige Sorgen. Markeringer, Ritualer Og Religion Etter 22. Juli, ed. Olaf Aagedal, Pål Ketil Botvar, and Ida Marie Høeg (Oslo: Universitetsforlaget, 2013), 89-92.

10 Ånund Brottveit and Sunniva Elisabeth Holberg, Tilstandsrapport for Den Norske Kirke 2013 (Oslo: Stiftelsen Kirkeforskning, 2013), 30.

${ }^{11}$ Research on constitutional and legal aspects of religion in Norway is extensive and scholars have written on contemporary politician's personal ties to religious and Christian groups. See for instance Torkel Brekke, Gud I Norsk Politikk: Religion Og Politisk Makt (Oslo: Pax, 2002). Nevertheless, the history of the Bible within Norwegian politics remains to be investigated.

${ }^{12}$ Jacques Berlinerblau, Thumpin' It: The Use and Abuse of the Bible in Today's Presidential Politics (Louisville: Westminster John Knox Press, 2008). "The Bible in the Presidential Elections of 2012, 2008, and 2004, and the Collapse of American Secularism," in Interested Readers: Essays on the Hebrew Bible in Honor of David J. A. Clines, ed. David J. A. Clines, et al. (Atlanta: Society of Biblical Literature, 2013); Yvonne Sherwood, "Bush's Bible as a Liberal Bible (Strange Though That Might Seem)," Postscripts: The Journal of Sacred Texts and Contemporary Worlds 2, no. 1 (2006). Bruce Lincoln, "Bush's God-Talk," in Political Theologies: Public
} 
elsewhere argued for continuity rather than discontinuity in the function of the Bible in the rhetoric of Republican and Democrat presidents of the US. ${ }^{13}$ George W. Bush's public presentation of the Bible in his Address the evening of September 11, 2001 should therefore not be considered as an exception to the rules that US presidents have followed when biblical references or allusions are weaved into their speeches. Barack Obama has been hailed and regarded as an ideological counterpart to George W. Bush in several political areas. Nonetheless, like Bush, Obama used the Bible to publicly profess his religious conviction and to vaguely and sparsely refer to Scripture in ways that signaled biblical literacy to the religious voters while not provoking secular voters to discard him. ${ }^{14}$ These two Protestant Christians would as presidents bring biblical content more explicitly to the fore in his speeches in situations where the office of the President was used to address words of compassion to a people painfully experiencing a tragic loss. ${ }^{15}$ The book of Psalms worked for Obama in several of these situations, as it had done for Bush on 9/11.

When questions about the role of religion in Northern Europe and United States are raised it is often with variations on the theme "the religious America and the secular Europe". ${ }^{16}$ A North American sociologist has on the basis of extensive field work in Denmark concluded that the levels of religiosity with regard to church attendance and privately held beliefs are "remarkably low" in Scandinavia. ${ }^{17}$ Elsewhere the same scholar refers to surveys where 3 percent of Swedes answer 'yes' to the question of whether they agree with the utterance that the Bible is "the actual/literal word of God", whereas 33 percent of North Americans in the

Religions in a Post-Secular World, ed. Hent de Vries and Lawrence Eugene Sullivan (New York: Fordham University Press, 2006). Jeffrey S. Siker, "President Obama, the Bible, and Political Rhetoric," Political Theology 13, no. 5 (2012).

${ }^{13}$ Ole Jakob Løland, "Obamas Effektive Bibel," Kirke og Kultur 119, no. 2 (2014).

${ }^{14}$ This communication to the religious, primarily Protestant, base is what Bruce Lincoln has "the linguistic equivalent to winks and nudges". Lincoln, 271. Jacques Berlinerblau has called attention the ways in which these biblical references were often not explicitly articulated, a result of Bush's deliberate strategy. Berlinerblau, "The Bible in the Presidential Elections of 2012, 2008, and 2004, and the Collapse of American Secularism," 210. In words of Janet R. Jakobsen and Ann Pellegrini, "Obama, like Bush, Clinton, and Reagan before him, desires to build a political base that is simoultanously Christian and secular. Janet R. Jakobsen and Ann Pellegrini, "Obama's Neo-New Deal: Religion, Secularism, and Sex in Political Debates Now," Social Research 76, no. 4 (2009): 1239.

15 "As president Reagan took on this role with the tragedy of the Space Shuttle Challenger (January 28, 1986), and even more significantly as President George W. Bush took on this role in the aftermath of the 9/11/2001 terrorist attacks, so also President Obama became Pastor Obama in the days after the tragic shootings on January 8, 2011 in Tucson, Arizona." Siker, 605-06.

${ }^{16}$ Peter L. Berger, Grace Davie, and Effie Fokas, Religious America, Secular Europe?: A Theme and Variations (Aldershot; Burlington: Ashgate, 2008).

${ }^{17}$ In an article the sociologist Phil Zuckerman refers to the low levels of religiosity in Denmark and Sweden, the levels attributed to these two countries is also commonly found in statistics on religiosity in the third Scandinavian country, Norway. Phil Zuckerman, "Why Are Danes and Swedes So Irreligious?," Nordic Journal of Religion and Society 22, no. 1 (2009): 55. 
United States confirm that they do so. ${ }^{18}$

On the background of this U.S.-Scandinavia divide it may be understandable that the Norwegian Prime Minister does not refer to the Bible once in his historical speech.

Nevertheless, holding the speech as the leader for a country with a Protestant majority and established national church, this absence has to be explained. Moreover, if Stoltenberg were to use the Bible, which Bible would it be? In other words, does a Norwegian Prime Minister have a Bible that might be reserved for other occasions?

The focal point of analysis here is the question about what the Bible could do for these two leaders of their nations in this time of national crisis and collective grief after the attacks. ${ }^{19}$ The example of the US leader serves to explore some of the possible meanings of the $9 / 11$ analogy to the terrorist attack on July 21, 2011 in Norway. This exploration is, however, primarily meant to make sense of the Norwegian case. The premise here is that by comparing the two, we can cast light on the role of religion, particularly the absence of the Bible, in Jens Stoltenberg's historical speech. In that way a preliminary theory about the role of the Bible in Norwegian politics might be formulated.

\section{Bush's 9/11 Address to the Nation}

When George W. Bush addressed his nation on September 11, 2001 he did so as elected president of a state without religion constitutionally. In principle George W. Bush served as a secular head of state, given that the First Amendment of 1791 to the Constitution prohibits any active promotion or privileging of a particular confession or religion on the part of the federal state. Although several American colonies had religious establishment, ${ }^{20}$ the Federal Constitution contains a clear principle of disestablishment: No Federal Government can set up a church or aid a specific religion. The office of the Presidency of the United States has no confession, although it is constitutionally obliged to promote policies that make a free exercise of religion in principle possible. These two principles, the one of disestablishment and one of religious freedom, work in tandem in the US model for relations between state

\footnotetext{
${ }^{18}$ Society without God: What the Least Religious Nations Can Tell Us About Contentment (New York: New York University Press, 2008), 25.

${ }^{19}$ This inquiry is particularly indebted to Brennan Breed's imperative the field of reception history of the Bible to move from asking about the meaning of biblical texts to "the work" they can perform. Brennan W. Breed, Nomadic Text: A Theory of Biblical Reception History (Bloomington: Indiana University Press, 2014), 117. ${ }^{20}$ Claudia E. Haupt, "Transnational Nonestablishment (Redux)," in Religion, Secularism, \& Constitutional Democracy, ed. Jean L. Cohen and Cécile Laborde (New York: Columbia University Press, 2016), 224.
} 
and church, government and religion. While religious groups as Evangelical Christians in the United States tend to emphasize the principle of free exercise secularists focus on the principle of disestablishment. ${ }^{21}$ When George W. Bush deliberately transcends the secularist distinction between religion and politics by invoking words of what is considered by many as Holy Scripture, he can be considered to enact the principle of free exercise. On background of a secular office in the 9/11 address he demonstrates how the constitution allows for the freely chosen religious faith to be expressed in public. Perhaps because the president is seen in the supposedly secular space of the Oval Office he can conquer this space with his explicit religious belief. This transgression vis-à-vis modern secularism can be understood as a triumph over one of the Republican's named enemies: North American secularism.

This triumphal reclaiming of space is not Bush's invention as rituals are collectively formed and produced. The US congress made In God We Trust into the official motto of the country in the late 1950s and Ronald Reagan as the president that gave the highest number of addresses to the nation from the oval office often concluded his speech with the words "God bless the United States of America". This core element of the ritual was repeated by George W. Bush September 11, 2001.

Addressing a nation that has witnessed the airborne terrorist attacks against United States that caused the deaths of more than 3,000, Bush starts his speech by stating the obvious or what everybody already new: The US had been hit by "deadly terrorist acts". ${ }^{22}$ Already in the third sentence of the speech the president invokes the contrast of good and evil, stating that “[t]housands of lives were suddenly ended by evil, despicable acts of terror." Through contemplating how "the pictures of airplanes flying into buildings... have filled us with disbelief" the speaker establishes an "us" under threat, morally and existentially. In the next sentence the president provides the viewer of the speech a reason for the "evil": "These acts of mass murder were intended to frighten our Nation into chaos and retreat, but they have failed. Our country is strong," the president declares with a stable and steady voice, as if the listener is to feel secure and protected. He assures that the adversaries of the Nation have already failed; it is implicit that the Nation has already triumphed since it is strong.

\footnotetext{
${ }^{21}$ Ann Pellegrini, "Religion, Secularism, and a Democratic Politics of "as If"," Social Research 76, no. 4 (2009): 1347.

${ }^{22}$ All quotations of Bush's Address is from the transcript on George W. Bush, "Address to the Nation September 11, 2001," http://www.presidency.ucsb.edu/ws/?pid=58057.
} 
Bush assures the viewer that " $\mathrm{t}]$ errorist attacks can shake the foundations of our biggest buildings", but the Nation is strong independtly of this since those responsible for "the acts of mass murder... cannot touch the foundation of America". Their attack is in vain, since America remains strong. Moreover, this national strength is the very reason for the attack, according to the president: "America was targeted for attack because we're the brightest beacon for freedom and opportunity in the world." This rhetorician knows the terrorists' intentions. As "the brightest beacon" this "America" can be seen by peoples and nations from far away and can help them and guide them on their routes. This is a powerful metaphor for American Exceptionalism that recalls and alludes to John Winthrop's vision of the New England in the New World as the shining "city upon a hill", with references to the Gospel of Matthew 5:14. "America" is exceptional for its "light" to the nations.

In the second part of the speech Bush tells about the actions already taken by the government, something that confirms what he enacts with the speech itself: However much the American society appears to be under attack the institutional order of his Federal government is intact. His address demonstrates this institutional strength through the power and willingness to speak. This image of firmness and strength is perhaps modified by the next speech act on the president's part: he asks the viewers to pray for "all those who grieve, for the children whose worlds have been shattered, for all whose sense of safety and security has been threatened". Like a pastor leading a congregation, the president asks his community to gather in prayer. "The Nation" is strong, but there are nonetheless elements of it that are threatened. Prayer can make the whole nation stronger; the speaker calls for wholeness and unity with the help of a transcendent power. Moreover, the president not only calls his people to pray, but has set forth an example: He himself is to pray for these elements: "I pray they will be comforted by a power greater than any of us, spoken through the ages in Psalm 23: 'Even though I walk through the valley of the shadow of death, I fear no evil, for You are with me."”

The president's biblical belief is a civil religion in the classical sense of Bellah's analysis: ${ }^{23}$ First, it comes particularly to expression in national rituals (such as an Address to the Nation). Second, it displays a non-sectarian belief in a deity that is not even specifically Christian ("a power greater than any of us"). Third, behind this civil religion "lie Biblical archetypes", even

\footnotetext{
${ }^{23}$ Robert N. Bellah, "Civil Religion in America," Daedalus 96, no. 1 (1967).
} 
more so; in front of it lie biblical citations. ${ }^{24}$

Within this ceremonial framework of civil religion the Bible functions to enact the vision of the head of the state of a strong and united America, an imagined fellowship of free citizens that remains invulnerable to foreign forces that destroy even the tallest buildings. Not even in "the valley of the shadow of death" left by the terrorist attacks is there any reason to "fear evil" in the biblical sense. Biblical faith confirms America's triumph over its enemies. As the great power protecting "the brightest beacon for freedom and opportunity in the world", the biblical God stands behind the ideals of liberal democracy, individual rights and opportunities for all provided by the free market. The great power that biblical faith relies on blesses "the great nation" that provides light for all the nations with its liberal freedom. Bush's Bible is the liberal one. It aims at creating a vague sense of union, with an appeal to common and self-evident values; ${ }^{25}$ the slogans of modern political and economic liberalism.

\section{The context for the role of the Church after Norway's 9/11}

Jens Stoltenberg was the Prime Minister of Norway for nine years, leading a Labor Party government for one year (2000-2001) and a center-left coalition with the Labor Party as the largest among the three in government for eight years (2005-2013). The terror attacks in Norway took place on July 22, 2011. The first was launched against the Government building in the center of Oslo and the bomb left eight dead and several others injured. The second was a massacre at the island Utøya outside of Oslo, where the Labor Party's Youth were gathered for their summer camp, causing 69 deaths. In other words, the target was Stoltenberg's ruling Labor Party, accused in the terrorist's "Manifest" of allowing the combination of Islamic migration, multiculturalism and feminism to break down the terrorist's imagined ethnic and national purity of Norway. His violent revolt against the Government was to spark an armed resistance movement in Norway in the process of a return to the "Christian Europe". ${ }^{26}$

Until 2012 the Norwegian Constitution demanded that at least half of the ministers in the Government were members of the Church of Norway; the Evangelical-Lutheran Church that was declared in the 1814 Constitution as the country's official religion. Jens Stoltenberg was among the Norwegians that had left the Church and was no longer a member, although 76,9

\footnotetext{
${ }^{24}$ Ibid., 8, 18.

${ }^{25}$ Berlinerblau, Thumpin' It: The Use and Abuse of the Bible in Today's Presidential Politics, 83.

${ }^{26}$ Jone Salomonsen, "Graced Life after All? Terrorism and Theology on July 22, 2011," Dialog 54, no. 3 (2015): 250.
} 
$\%$ of his people still formally adhered to the Evangelical-Lutheran confession. ${ }^{27}$ Moreover, he was also the leader of a political party in a historically ambivalent relation to the Church of Norway. In the Labor Party's struggle for political hegemony bishops and leaders in the Church of Norway had been voices of opposition to the party's effort to create the Welfare state. ${ }^{28}$ All the same, when Stoltenberg appeared in the Cathedral two days after the terrorist attacks the meaning of this appearance was nurtured by nearly five centuries old tradition of state-church relations. As the church historian Dag Thorkildsen has concluded, "from the age of Reformation in 1536-37 to the Norwegian Parliament's changes of the Constitution in May 2012, the relation between Church and state remained in principle the same". ${ }^{29}$ In April 2008, however, all parties in the Parliament agreed to take major steps towards nonestablishment: the state was no longer to have any official religion and the Church of Norway was to gradually become autonomous in relation to the state. Nonetheless, it was to be mentioned in the new Constitution and the revised paragraph 16 of this new Constitution is still formulated in terms of establishment: "The Church of Norway, an Evangelical-Lutheran church, will remain the Established Church of Norway and will as such be supported by the State.” ${ }^{\text {, }}$ Summed up, at the time of this speech Stoltenberg's cabinet governed a process of loosening up the strong historical ties between Church and state in Norway, without the purpose of arriving at a separation as practiced with the US model. The hesitance to break with this history of a state-controlled national church promoting religious homogeneity, expressed through the decisions of a center-left government led by Stoltenberg, is significant. When Stoltenberg's cabinet chose to participate in the memorial service in the Cathedral they revoked this past, for instance through the performance of strong bonds between Church, Government and Monarchy. The political establishment sought in this way implicit theological and religious legitimacy in the exceptional national crisis, based on an “irrevocable latency", in the words of de Vries. Furthermore, the media's transmission of this event strengthened the sense of emotional unity and national consensus that this memorial

\footnotetext{
${ }^{27}$ Brottveit and Holberg, 47.

28 "The Church essentially feared the economic calculating state that measured goodness and truth in terms of materialistic categories. Between Church and Labor party there was a clash of moral visions." Aud V.

Tønnessen, "The Church and the Welfare State in Postwar Norway: Political Conflicts and Conceptual Ambiguities," Journal of Church and State 56, no. 1 (2014): 34.

${ }^{29}$ Dag Thorkildsen, "The Role of the Church in Contemporary Norway: Changed Relations Between. State and Church," Kirchliche Zeitgeschichte 25, no. 2 (2012): 273.

${ }^{30}$ Thanks to Helge Årsheim for guiding my attention to this loaded official translation of the Constitution of 2012, originally written in Norwegian. Stortinget, "The Constitution, as Laid Down on 17 May 1814 by the Constituent Assembly at Eidsvoll and Subsequently Amended, Most Recently in May 2016," https://www.stortinget.no/globalassets/pdf/english/constitutionenglish.pdf.
} 
ritual was aimed at. ${ }^{31}$ But this evoking of the past and atmosphere of unity was not merely an elite phenomenon. The creation of the Cathedral as one of the main centers of the public response to the terror was also the result of mass ritualization on the people's part, lightning candles within the Cathedral and not least, putting flowers in layers on the street outside the church building, resulting in what became known as "the sea of roses" (Norwegian:

Rosehavet). This ritual was not officially conducted by agents of the Church but rather an expression of popular grief and ritualization that cannot easily be deemed as either a secular or religious practice. In the words of Terje Stordalen, "the rose installation could also be taken to visualize how the Church of Norway is historically and topographically woven into the fabric of the nation and the city to the extent that it is difficult to distinguish between ecclesiastical and civil values". ${ }^{32}$ The red rose, being the symbol of the Labor Party as well as a flower that many Norwegians leave on the chest during a funeral, ${ }^{33}$ served as a powerful symbol of grief.

\section{Stoltenberg's Speech on Norway's 9/11}

Stoltenberg is given space for his speech in the middle of the service on this day. $\mathrm{He}$ addresses the Norwegian royal family, the leader of the Labor Party's Youth Eskil Pedersen and everyone else present in the room, without any particular attention given to religious authorities, for instance the bishops leading the service. Stoltenberg early on establishes a narrative about the terror attack: "It is nearly two days since Norway was hit by the worst atrocity it has seen since the Second World War." ${ }^{34}$ He invokes another national trauma and the individual fates of the victims of the terror are enrolled within the wider national narrative about Norway. Moreover, the speaker implicitly draws an analogy between the Nazi occupiers and the Norwegian terrorist, of whom the identity had been revealed by the police and disseminated in the media coverage. Nonetheless, this inscription of the event into historical time is modified by his claim that the two days constitutes "an eternity". This creates or confirms the feeling of a fragmented time in the aftermath of the shock of the

\footnotetext{
${ }^{31}$ Ida Marie Høeg, "Silent Actions - Emotion and Mass Mourning Rituals after the Terrorist Attacks in Norway on 22 July 2011," Mortality 20, no. 3 (2015): 198.

32 Terje Stordalen, "The Trail of Roses. Time, Media, and Space in Memory Practices in Oslo after 22 Juli 2011," in The Formative Past and the Formation of the Future: Collective Remembering and Identity Formation, ed. Saphinaz-Amal Naguib and Terje Stordalen (Oslo: Novus Press, 2015), 333.

${ }^{33}$ From the author's personal experience of leading burial ceremonies as pastor in the Church of Norway in the Oslo region.

${ }^{34}$ All quotations from Stoltenberg's speech are from the Norwegian government's web arhive: Jens Stoltenberg, "Address by Prime Minister in Oslo Cathedral," Publisher Office of the Prime Minister, https://www.regjeringen.no/en/aktuelt/address-by-prime-minister-in-oslo-cathed/id651789/.
} 
event. ${ }^{35}$ The Prime Minister deepens this sense of painful fragmentation when he states that "there have been hours, days and nights filled with shock, despair, anger and weeping".

He further states that "today is a time for mourning" and states the obvious that the viewers already know: "92 lives have been lost. Several people are still missing." 36 There is a powerful contrast operative in the speaker's telling of what is merely a fact about the tragedy and the apparent difficulties he has for doing so without becoming too emotional. The motif of the Second World War fuels the sense that the Prime Minister himself is involved in the struggle on behalf of the nation, to emotionally speak up in sincere compassion and later in the speech when he rhetorically declares that "we will never give up our values". "We" are in a struggle. Compared to George W. Bush's 9/11 speech, however, the motif of "evil” appears later in Stoltenberg's speech. Moreover, Bush emphasizes the terrorist acts and when he assures that "I implemented our Government's emergency response plans" he highlights the potent agency of his Government. The Norwegian chief officer, in contrast, places his emphasis on the victims and never refers to any particular political actions or extraordinary measures implemented by himself or his Government. Stoltenberg's response to the terrorism in this speech is political in a broad sense when he proclaims that "our response is more democracy, more openness, and more humanity". But his response is at the same time highly emotional, in form as well as in content, as the last words of his speech directed to the victims' family and friends exemplify: "Now life is at its darkest for you. I want you to know that we are there for you." Throughout his speech Stoltenberg focuses on the massive scale of the losses and the "incomprehensible" nature of the "horror". Compared to Bush's speech, this results in a less potent or powerful image of himself, his government and his people. The Prime Minister appears as a compassionate witness rather than a powerful chief in command, which is further underlined by his tale of two individuals that lost their lives in the terror: "Monica" that worked at the island Utøya for 20 years, and "Tore Eikeland" who was "the leader of the Labour Youth League in Hordaland". Furthermore, unlike the speaker in the US case, in the Norwegian case the Prime Minister himself knew these two and several other victims personally. Having already exposed his emotional state, the Prime Minister further strengthens the image of a compassionate and vulnerable national leader when he also informs the listeners that "I knew several" [of the victims].

\footnotetext{
${ }^{35}$ Rafoss Tore Witsø, "Meningsløs Terror Og Meningsfylt Fellesskap: Stoltenbergs Taler Etter 22. Juli," Sosiologisk tidsskrift 23, no. 1-2 (2015): 19.

${ }^{36}$ At the time the Norwegian authorities did not have the correct number of the casualties.
} 
This sense of vulnerability appears to be one of the feelings the North American 9/11 speech attempts to target. Bush fixes parts of his speech on the greatness of the American nation, the unshakable foundations of it and his government's firm actions within the shocking circumstances. On the top of this, he affirms within a minute into his talk that he knows the reasons for the deadly acts: They were committed because the great American nation is nothing less than "the brightest beacon for freedom and opportunity in the world". By contrast, Stoltenberg never claims to know the reasons for the terror committed. While Bush rationalizes the acts, Stoltenberg cultivates the sense of their incomprehensibility and meaninglessness. Stoltenberg also draws his image of the nation that is in the midst of a "national tragedy"; he declares that "[w]e are a small country, but a proud people." This image of the Norwegian nation is distinctly different from Bush's American Exceptionalism; the exceptional about Norway is that although the country is small, its people are proud. The consequence and manifestation of this national quality Stoltenberg claims for his people can be seen in what he describes and prescribes as the Norwegian response to the terror: "more democracy, more openness, and more humanity". In this way, Stoltenberg's speech moves from the tragic to the epical. Evil has happened, people have been lost, but "we" do not give up our values but respond by creating more democracy, openness and humanity. This epical outcome of Stoltenberg's proud people is prepared right in the beginning of his speech, where he connects the terror to the Second World War. Since the heroic resistance to German occupation has been a dominant theme in the cultural memory and national history of the war, this parallel gives Stoltenberg's performance an epical tone in the midst of his emphasis on the tragic. $^{37}$

Stoltenberg could have drawn the Church into this national memory of the war and struggle for national independence. As said, the Lutheran confession was explicitly inscribed into the national identity in the Constitution and Declaration of Independence of 1814. Besides, during the Nazi occupation all the bishops and $93 \%$ of the clergy in the Church of Norway resisted nazification and the vast majority of the church broke with the state in 1942. The Church became a dominant institutional force in the civil resistance to Nazi occupation. ${ }^{38}$ Nonetheless, Stoltenberg made no explicit claim to this religious legacy in the Norwegian

\footnotetext{
${ }^{37}$ Tore Witsø, 22.

${ }^{38}$ Tønnessen, 17.
} 
society. And although Stoltenberg's discourse to a large degree was driven by metaphors, ${ }^{39}$ no metaphors that are commonly and specifically related to Lutheranism, Christianity or religion appeared. Markedly different from the US president, Stoltenberg made no reference to a transcendent power in a way that would indicate a civil religion at work. ${ }^{40}$ Moreover, despite having a Protestant confession as its official creed and speaking in the midst of this Protestant state church, the principle of "sola Scriptura" formed no basis for Stoltenberg's speech. I suggest that Stoltenberg's performance was successful in the sense that this orator achieved to integrate Norwegians' sense of meaninglessness as well as meaningfulness in the aftermath of the terror, as argued by the sociologist Tore Wits $\varnothing$ Rafoss. My hypothesis is that this success could not be achieved with the rhetorical use of the Bible, particularly not in George W. Bush's form of biblical triumphalism, despite the fact that Stoltenberg gave the speech within the religious space of the Cathedral,. Even as standing in the very place in the cathedral where readings from the Bible is done as part of the regular service, any person in Stoltenberg's position that day would likely have mourned with the nation using a secular vocabulary. This is also due to the division of labour between the clergy conducting the service on one hand and the political leader being given the room to speak on the other. The service being filled with religious symbols and meaning makes it appropriate for the politician to downplay rather than to make explicit the ties between the state and the church. It is not only the recently instigated process of disestablishment that encourages such a non-confessional political speech. The fact that Stoltenberg is the primary leader of an increasingly multi-religious society and that several of the victims were non-Christians also leads to the secular tone of his speech.

If Stoltenberg did not have a Bible for this occasion, does it mean that he as a Norwegian politician and statesman did not possess any Bible comparable to George W. Bush's Liberal Bible? If one surveys Stoltenberg's speeches after the Norwegian 9/11 and his New Year's Addressees that can be compared to a US Address to the Nation, the Bible as reference for his speeches is absent with one exception: The Prime Minister's New Year's Address from 2010.

\section{Stoltenberg's Cultural Bible}

In 2008 the world was hit by the most severe financial crisis since the Depression in the

\footnotetext{
${ }^{39}$ Tore Wits $\varnothing, 17$.

${ }^{40}$ This confirms previous findings on the Norwegian case. Inger Furseth, "Civil Religion in a Low Key: The Case of Norway," Acta Sociologica 37, no. 1 (1994).
} 
1930s. In the address that any Norwegian Prime Minister is expected to give on national TV every New Year's Day, Stoltenberg chose for his recorded speech for January 1, 2010 to focus on Norway's economic policies. The speech starts off with a presentation of the biblical as "ancient wisdom": 41

Among the first public buildings we know of from the earliest civilisations are granaries. They were used to provide emergency relief in years when crops failed. We remember the story of Joseph advising Pharaoh to build up a store of grain because the seven good years would be followed by seven years of famine. This is ancient wisdom: we should save when times are good so as to be prepared for hard times. ${ }^{42}$

The biblical tale of "Joseph advising Pharaoh" does not bear traces of any divine will, in Stoltenberg's reading, but of "ancient wisdom". The story from the Bible is used by Stoltenberg to refer to an accumulated experience or knowledge from "the earliest civilizations"; Stoltenberg's Bible can give us knowledge of ancient cultures and the experiences they made. Arguing in terms that remind some of the viewers of modern Keynesianism that a graduated economist like Jens Stoltenberg would be familiar with, he nonetheless bolsters modern economic theory with an ancient story we may happen to remember. Stoltenberg expects the listener to be familiar with the story from the Bible that works to illustrate that his government follows ancient common sense: to be prepared for hard times.

We have been able to spend more during these difficult times because we were careful when times were good. In this respect, you could say that we have followed the advice Joseph gave to Pharaoh, albeit in a rather different way. The Egyptians built granaries. We built the Government Pension Fund. ${ }^{43}$

Ancient wisdom and macroeconomics melt together; Stoltenberg's government was "careful when times were good”. Its policies ensured that Norway built the state's Pension Fund.

The biblical story is singled out because it is the one "we remember", according to the Prime

\footnotetext{
${ }^{41}$ Thanks to Sven Thore Kloster at the University of Oslo for this reference.

42 Jens Stoltenberg, "Prime Minister's New Year's Address 2010," Publisher Office of the Prime Minister, https://www.regjeringen.no/en/aktuelt/prime-ministers-new-years-address-2010/id589483/.

${ }^{43}$ Ibid.
} 
Minister. Furthermore, Stoltenberg's government has like all former Norwegian governments invested considerable efforts and money to ensure that pupils in Norwegian schools and baptized members of the state Church learn stories such as this one, representing "ancient wisdom". There might be other forms of "ancient wisdom" available; the speech does not tell. It does not refer to other possible forms of wisdom from the ancient past. Anyhow, Stoltenberg reproduces a soft version of the notion from Jonathan Sheehan's "Enlightenment Bible" of the Bible as a repository of civilization and valuable human culture to learn from. As a sole example of Stoltenberg's Bible at work in Norwegian political rhetorics it all the same attests to the marginal role of the Bible in this context: the Bible is mostly absent from this level of Norwegian politics, the discourse of the Prime Ministers.

This was also the case during the governance that preceded Stoltenberg's periods as the Prime Minister of Norway, in the years 1997-1998 and 2001-2005 when Kjell Magne Bondevik held the highest political office of the country. He was a politician from the only Norwegian party in the parliament that officially bases their politics on the Bible: The Christian Democratic Party [Kristelig Folkeparti]. This party claims to have withdrawn the values which their political program is based upon from the Holy Book of Christianity. Nonetheless, although Bondevik was an ordained pastor and front figure of an officially "biblical" political party, Bondevik was careful not to indulge in biblical rhetorics. ${ }^{44}$ Bondevik himself rarely referred to the Scripture in official discourses as Prime Minister during his governance, and only in very general terms. Most often, he would legitimize his policies with reference to the "Christian cultural heritage" as well as the imagined humanistic values of Norway. ${ }^{45}$

\section{Conclusion}

The evidence this article has focused on and played some variations with over the theme "the religious America and the secular Europe" is limited. The two speeches in focus are, however, illuminating test-cases for the role of the Christian religion and its canonized literature in times when these nations feel threatened to an extreme degree. George W. Bush's Liberal Bible contains little text and is vague in its meaning, but functions to produce an imagined

\footnotetext{
${ }^{44}$ In speeches at internal meetings in the party Bondevik warned the active members of his party of conflating the Bible and the politics. To him, however much they would relate to one another, the two entities were separate. The Bible was no "lexicon" [oppslagsverk] for politics. Kjell Magne Bondevik, "Kristendemokratiet Som Toneangivende Alternativ," http://virksommeord.uib.no/taler?id=1084.

${ }^{45}$ As he stated in his inauguration speech for his government in 2001. http://virksommeord.uib.no/taler?id=225 Accessed 10.08.15.
} 
sense of national unity in the United States on the level of presidential discourses, particularly in times of national crisis as on September 11, 2001. As seen, in the US context of national crisis the Bible can function to bolster the already biblically loaded notion of America as a light for the nations in its attainment of freedom. In the Norwegian context of such a crisis the religious space can be regarded to be given a more central role. For some time the Cathedral pertaining to the nation's official religion from its conception was the epicenter of the mass ritualization of grief. Nevertheless, within this religious space there is a clear division of labor, as if the separation of state and church was taking place within it. Since the memorial service is so filled with religious meaning, the Prime Minister can carve out space for the secular within this religious space. Therefore he is in no need of a Bible as the revealed Word of God. As a public figure is in possession of one Bible only; a Cultural Bible capable of reminding Norwegians of the wisdom in ancient civilizations. But this is not a Bible that can adequately express the Prime Minister's compassion for the Norwegian people and its victims after a terror attack, nor can it bring the longed-for sense of national unity into existence. When this nation is in crisis its officials may gather in a Cathedral and its people may spontaneously decorate the church property with a sea of roses. But when its most precious values and liberal democracy are to be defended by the Prime Minister, it will most likely be expressed in a secular language. Having made his way into an orchestrated church ritual in times of terror, the Norwegian statesman will comfort his people from within the religious space through a secular vocabulary. The secular language is comforting. The lack of biblical references makes it inclusive and therefore credible.

\section{Bibliography}

Aagedal, Olaf. "Sørgjestad Og Kampplass. Stortorget Og Oslo Domkyrkje Etter 22. Juli." In Den Offentlige Sorgen. Markeringer, Ritualer Og Religion Etter 22. Juli, edited by Olaf Aagedal, Pål Ketil Botvar and Ida Marie Høeg. Oslo: Universitetsforlaget, 2013.

Bellah, Robert N. "Civil Religion in America." Daedalus 96, no. 1 (1967): 1-21.

Berger, Peter L., Grace Davie, and Effie Fokas. Religious America, Secular Europe?: A Theme and Variations. Aldershot; Burlington: Ashgate, 2008.

Berlinerblau, Jacques. "The Bible in the Presidential Elections of 2012, 2008, and 2004, and the Collapse of American Secularism." In Interested Readers: Essays on the Hebrew Bible in Honor of David J. A. Clines, edited by David J. A. Clines, J. K. Aitken, Jeremy M. S. Clines and Christl M. Maier, 197-218. Atlanta: Society of Biblical Literature, 2013.

. Thumpin' It: The Use and Abuse of the Bible in Today's Presidential Politics. Louisville: Westminster John Knox Press, 2008.

Bondevik, Kjell Magne. "Kristendemokratiet Som Toneangivende Alternativ." http://virksommeord.uib.no/taler?id=1084. 
Breed, Brennan W. Nomadic Text: A Theory of Biblical Reception History. Bloomington: Indiana University Press, 2014.

Brekke, Torkel. Gud I Norsk Politikk: Religion Og Politisk Makt. Oslo: Pax, 2002.

Brottveit, Ånund, and Sunniva Elisabeth Holberg. Tilstandsrapport for Den Norske Kirke 2013. Oslo: Stiftelsen Kirkeforskning, 2013.

Bush, George W. "Address to the Nation September 11, 2001." http://www.presidency.ucsb.edu/ws/?pid=58057.

Crossley, James G. Harnessing Chaos: The Bible in English Political Discourse since 1968. London: Bloomsbury T\&T Clark, 2014.

Furseth, Inger. "Civil Religion in a Low Key: The Case of Norway." Acta Sociologica 37, no. 1 (1994): 39-54.

Harris, Paul. "'Norway's 9/11': At Least 80 Feared Dead in Double Attack on Norwegian Capital and Holiday Island." Associated Newspapers.

Haupt, Claudia E. "Transnational Nonestablishment (Redux)." In Religion, Secularism, \& Constitutional Democracy, edited by Jean L. Cohen and Cécile Laborde, 222-45. New York: Columbia University Press, 2016.

Hormans, Charles. "Norway's 9/11?" National Affairs, Inc.

Høeg, Ida Marie. "Silent Actions - Emotion and Mass Mourning Rituals after the Terrorist Attacks in Norway on 22 July 2011." Mortality 20, no. 3 (2015): 197-214.

Jakobsen, Janet R., and Ann Pellegrini. "Obama's Neo-New Deal: Religion, Secularism, and Sex in Political Debates Now." Social Research 76, no. 4 (2009): 1227-54.

Johnson, Bradley A. "Currency of a Calling: The American Exception, the American Dream." Postscripts: The Journal of Sacred Texts and Contemporary Worlds 2, no. 1 (2006): 87-95.

Lincoln, Bruce. "Bush's God-Talk." In Political Theologies: Public Religions in a PostSecular World, edited by Hent de Vries and Lawrence Eugene Sullivan, 269-77. New York: Fordham University Press, 2006.

Løland, Ole Jakob. "Obamas Effektive Bibel." Kirke og Kultur 119, no. 2 (2014): 113-26.

Pellegrini, Ann. "Religion, Secularism, and a Democratic Politics of "as If"." Social Research 76, no. 4 (2009): 1345-50.

Salomonsen, Jone. "Graced Life after All? Terrorism and Theology on July 22, 2011." Dialog 54, no. 3 (2015): 249-59.

Sheehan, Jonathan. The Enlightenment Bible: Translation, Scholarship, Culture. Princeton: Princeton University Press, 2005.

Sherwood, Yvonne. "Bush's Bible as a Liberal Bible (Strange Though That Might Seem)." Postscripts: The Journal of Sacred Texts and Contemporary Worlds 2, no. 1 (2006): 47-58.

. "The God of Abraham and Exceptional States, or the Early Modern Rise of the Whig/Liberal Bible." Journal of the American Academy of Religion 76, no. 2 (2008): 312-43.

Siker, Jeffrey S. "President Obama, the Bible, and Political Rhetoric." Political Theology 13, no. 5 (2012): 586-609.

Stoltenberg, Jens. "Address by Prime Minister in Oslo Cathedral." Publisher Office of the Prime Minister, https://www.regjeringen.no/en/aktuelt/address-by-prime-minister-inoslo-cathed/id651789/.

. "Prime Minister's New Year's Address 2010." Publisher Office of the Prime Minister, https://www.regjeringen.no/en/aktuelt/prime-ministers-new-years-address2010/id589483/.

Stordalen, Terje. "The Trail of Roses. Time, Media, and Space in Memory Practices in Oslo after 22 Juli 2011." In The Formative Past and the Formation of the Future: 
Collective Remembering and Identity Formation, edited by Saphinaz-Amal Naguib and Terje Stordalen, 315-44. Oslo: Novus Press, 2015.

Stortinget. "The Constitution, as Laid Down on 17 May 1814 by the Constituent Assembly at Eidsvoll and Subsequently Amended, Most Recently in May 2016." https://www.stortinget.no/globalassets/pdf/english/constitutionenglish.pdf.

Thorkildsen, Dag. "The Role of the Church in Contemporary Norway: Changed Relations Between. State and Church." Kirchliche Zeitgeschichte 25, no. 2 (2012): 272-92.

Tore Wits $\varnothing$, Rafoss. "Meningsløs Terror Og Meningsfylt Fellesskap: Stoltenbergs Taler Etter 22. Juli." Sosiologisk tidsskrift 23, no. 1-2 (2015): 6-28.

Tønnessen, Aud V. "The Church and the Welfare State in Postwar Norway: Political Conflicts and Conceptual Ambiguities." Journal of Church and State 56, no. 1 (2014): 13-35.

Vries, Hent de. "Introduction." In Political Theologies: Public Religions in a Post-Secular World, edited by Hent de Vries and Lawrence Eugene Sullivan. New York: Fordham University Press, 2006.

Zuckerman, Phil. Society without God: What the Least Religious Nations Can Tell Us About Contentment. New York: New York University Press, 2008.

. "Why Are Danes and Swedes So Irreligious?". Nordic Journal of Religion and Society 22, no. 1 (2009): 55-69. 